\title{
Academic Stress and Depression among Medical Students
}

Rezki Perdani Sawai, Joki Perdani Sawai, Ummul Syamimi Lan Hawari, Abdul Rashid Abdul Aziz \& Roslee Ahmad

To Link this Article: http://dx.doi.org/10.6007/IJARBSS/v12-i1/12326

DOI:10.6007/IJARBSS/v12-i1/12326

Received: 08 November 2021, Revised: 11 December 2021, Accepted: 30 December 2021

Published Online: 17 January 2022

In-Text Citation: (Sawai et al., 2022)

To Cite this Article: Sawai, R. P., Sawai, J. P., Hawari, U. S. L., Aziz, A. R. A., \& Ahmad, R. (2022). Academic Stress and Depression among Medical Students. International Journal of Academic Research in Business and Social Sciences, 12(1), 2611-2620.

\section{Copyright: (c) 2022 The Author(s)}

Published by Human Resource Management Academic Research Society (www.hrmars.com)

This article is published under the Creative Commons Attribution (CC BY 4.0) license. Anyone may reproduce, distribute, translate and create derivative works of this article (for both commercial and non0-commercial purposes), subject to full attribution to the original publication and authors. The full terms of this license may be seen at: http://creativecommons.org/licences/by/4.0/legalcode

\section{Vol. 12, No. 1, 2022, Pg. $2611-2620$}

Full Terms \& Conditions of access and use can be found at http://hrmars.com/index.php/pages/detail/publication-ethics 


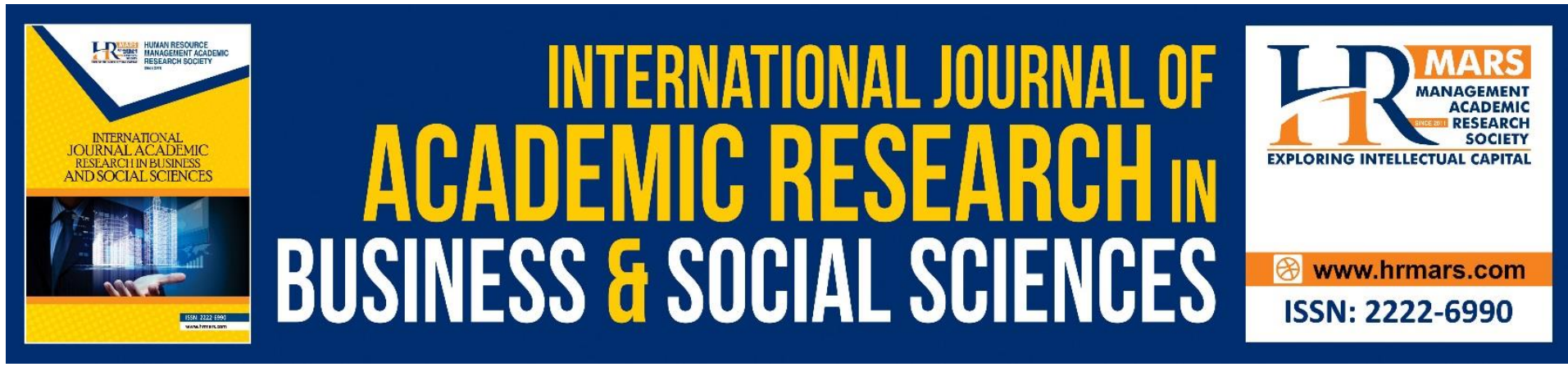

\title{
Academic Stress and Depression among Medical Students
}

Rezki Perdani Sawai ${ }^{1}$, Joki Perdani Sawai ${ }^{2}$, Ummul Syamimi Lan Hawari ${ }^{3}$, Abdul Rashid Abdul Aziz ${ }^{4}$ \& Roslee Ahmad ${ }^{5}$

1,3,4,5 Faculty of Leadership and Management Universiti Sains Islam Malaysia, Nilai, Negeri Sembilan, ${ }^{2}$ Faculty of Psychology and Education Universiti Malaysia Sabah, Kota Kinabalu,

Sabah

Corresponding Author Email: rashid@usim.edu.my

\begin{abstract}
Depression among university students is becoming a serious health issue in the country. Their vulnerability to higher rates of stressors has a negative impact on them as students as well as on their lives. This study investigates the level of academic stress and depression and the relationship between them among medical students at Universiti Sains Islam Malaysia (USIM). Questionnaires were given to 133 medical students at USIM comprising 3 sections covering demographic information, an academic stress inventory (SSI), and the Beck depression inventory (BDI). An analysis using Pearson's correlation coefficient found a positive and significant relationship between the two variables. This study provides information to counselors on the level of academic stress and depression among students, especially medical students. It also aims to increase awareness among university authorities and parents on the importance of maintaining the mental health of students and children.
\end{abstract}

Keywords: Academic Stress, Depression, Medical Students

\section{Introduction}

Depression and academic stress among university students have become a widespread problem across the country (Abadi et al., 2004). Students were found to be exposed to high levels of stress (Adlaf et al., 2001) which has in turn made them susceptible to academic stress (Ryan et al., 2018). According to Le Fevre et al (2003) these academic stressors include eustress and distress. Eustress refers to a positive psychological reaction to stressors that produces positive outcomes such as feelings of satisfaction and happiness while distress is a negative psychological reaction that contributes to negative outcomes such as anxiety, frustration, and depression (Simmons \& Nelson, 2001). Academic stress is perceived as distress that will lead to recurring potentially negative behaviours and potentially harmful health outcomes such as depression (Skipworth, 2011). In this study, academic stress refers to mental and emotional strain or tension arising from the demands of college life (Rahul \& Vikas, 2018). 
Depression is a condition characterized by sadness, loss of interest or satisfaction, low internal self-esteem, lack of sleep or appetite, decreased energy, and lack of focus (ToroTobar et al., 2016). Feelings and symptoms of depression can be acute or persistent, recur frequently, and can substantially affect the ability to perform daily activities (Bhowmik et al., 2012). This makes it difficult for people diagnosed with the disorder to complete their daily activities and maintain relationships. In the most serious situations, depression can lead to suicide (Dinas et al., 2011). Moreover, the poor quality of life experienced by the depressed can increase their susceptibility to medical issues, such as chronic heart disease, diabetes mellitus, and hypertension (Skevington \& McCrate, 2012).

Currently, mental illness is the second biggest health issue affecting Malaysians after heart disease. According to the National Health and Morbidity Survey (NHMS) 2017, at least one in 10 or 10 percent of the 5.5 million youth in the country have contemplated suicide. In addition, the study revealed that one in five suffer from depression while one in 10 teenagers experience emotional stress. Given that the young population is primarily composed of students, this has important and serious implications.

Depressive symptoms can have a major effect on the ability of college students to successfully meet academic requirements (Preeti \& Mustafa, 2013) with many feeling that they are not meeting the performance standards set (Sindhu, 2016). As a result, they feel frustrated and view things negatively and consider themselves as failures. This situation will certainly lead to various major problems in their academic life (Khadijatu, 2018). Various studies have been conducted to examine the relationship between academic stress and depression. For instance, Jayanthi, Thirunavukarasu and Rajkumar (2015) reported that adolescents with academic stress have a higher risk of depression than others. Similarly, Rahul and Vikas (2018) found that the level of academic stress is significantly influenced by student depression.

Though stress is generally prevalent among university students its degree varies among those from different courses. There are several factors associated with that. Medical students are more likely to get depressed compared to those in other courses as medical education is considered to be stressful and extremely challenging. A study by Jafri et al (2017) found that $54.6 \%$ of medical students had high levels of stress compared to $20.6 \%$ and $32 \%$ in engineering and humanities, and industrial courses, respectively. Academic stress is defined as an unpleasant situation experienced by students as a consequence of the demands that need to be met, thus triggering anxiety and affecting their studies (Arif \& Saodah, 2019). Academic stress experienced by students mostly comes from various demands at the university. There are four sources of academic stress that often occur among students, namely physical demands, task demands, role demands, and interpersonal demands (Desmita, 2009). A study by Nurhayati et al (2020) examining on the relationship between academic stress, resilience, and social adaptation by among 424 respondents found the three factors having a significant influence on the psychological well-being of students.

According to Kebede, Anbessie, and Ayano (2019), undergraduate medical education requires long-term learning and training that is extremely challenging. During this period, medical students acquire the knowledge, skills, and professional attitudes to prepare themselves for lifelong professional challenges. In addition, they typically experience stress 
due to the extensive syllabus, high levels of competition, and inability to cope with high parental expectations (Kumar \& Jadaun, 2019). Such factors prevent students from participating in extracurricular activities as much time is allocated to complete academic studies, and this contributes to stress (Cole et al., 2015). Each of these factors can be the reason why medical students are found to have higher levels of depression and anxiety (Dahlin et al., 2005). This stress affects their mental health resulting in sleep loss, poor concentration, lack of confidence in dealing with patients, loss of self-esteem, anxiety, depression, interpersonal conflict, substance abuse, and suicide attempts (Manjunath \& Kulkarni, 2013). This has a negative impact on overall health and can affect academic performance (Kadri et al., 2011).

Depression, also known as a major depressive disorder or clinical depression, is a common and serious mood disturbance. Those suffering from it experience persistent feelings of sadness and hopelessness and lose interest in activities they once enjoyed. Scholars have linked the state of depression with different psychological symptoms, including distress, depressive moods, and anguish (Błachnio et al., 2015) and suggest that it has an influential effect on both mental and physical processes (Sydenham et al., 2017). Those afflicted may exhibit physical symptoms such as chronic pain or digestion issues. Truschel (2019) mentions that to diagnose depression, the symptoms must be present for at least two weeks.

According to Oku et al (2015), 39\% of medical students have poor mental health status in the University of Calabar, Nigeria. In addition, $45 \%$ to $83 \%$ of them have suicidal thoughts and are at high risk of suicide. Therefore, it is important for medical schools to be mindful of their students' mental well-being because basically medical treatment involves taking care of the lives of others. If some mistake or failure occurs at that time, it puts the patient at risk and will have a negative impact on the profession itself. The inability of students to manage stress well can have a negative impact at work, such as burnout. Burnout adversely affects physicians, patients, and the health care system, where it has been shown that doctors who experience it are at higher risk of making poor decisions, having negative attitudes toward patients, and committing more medical errors (Kumar et al., 2016).

There are numerous studies on academic stress and depression among non-medical university students in Malaysia (Shamsuddin et al., 2013). However, there is a study that investigated the prevalence and sources of stress among medical students at USIM (Bahri et al., 2010). Thus, there are gaps in the academic literature with respect to studies examining academic stress and depression among medical students.

In Western countries, there is much literature on academic stress and depression among medical students. Such mental health studies have been a major concern of psychologists, as the number of fatal cases involving medical students, especially in western countries, has given rise to calls to take preventive action to address this problem (Coentre \& Góis, 2018). Studies in Malaysia also report that morbidity rates among Malaysian medical students is increasing (Shamsuddin et al., 2013). This study thus attempts to fill the gap and focuses on the level of academic stress and depression among medical students at USIM and the relationship between the two variables.

The objectives of this study were: 
1) To identify the level of academic stress among medical students at USIM.

2) To identify the level of depression among medical students at USIM.

3) To investigate the relationship between academic stress and depression among medical students at USIM.

\section{Methodology}

Quantitative research studies using surveys were employed in this study. Data was collected using a questionnaire. A total of 133 medical students from the Faculty of Medicine and Health Sciences at USIM were involved in this study. For depression, the researchers used the Beck Depression Inventory developed by Aaron T. Beck while the Student Stress Inventory developed by Aziz (2016) was used to gauge academic stress. The instruments were randomly distributed among medical students with those being in Year 1 to Year 6 being the main criterion. The questionnaire was distributed directly to all respondents using Google Form. This study used descriptive and inferential statistics. The descriptive statistics aimed at gauging the level of academic stress and depression while Pearson correlation was used to examine the relationship between the two factors.

\section{Results}

Table 1 shows three levels of academic stress (low, moderate, and severe levels) among medical students at USIM. The findings show that 70 students (52.6\%) had low levels of academic stress, 60 (45.1\%) had moderate levels, and 3 (2.3\%) experienced severe levels of academic stress.

Table 2 reveals four categories of student depression, namely normal, mild, moderate, and severe. A total of 78 respondents reported severe levels of depression (58.6\%), 55 (41.4\%) had moderate levels of depression, and none reported normal and mild levels of depression.

Pearson correlation was used to determine whether there was a significant relationship between academic stress and depression. The results of the study as shown in Table 3 indicate that academic stress and depression have a high and significant correlation while the $r$ value indicated a positive and significant relationship between the two factors ( $r$ $=.656, \mathrm{n}=133, \mathrm{p}<0.05)$.

Table 1: Level of Academic Stress

\begin{tabular}{ccc}
\hline \multicolumn{1}{l}{ Level } & Frequency & Percentage \\
\hline Mild & 70 & 52.6 \\
Moderate & 60 & 45.1 \\
Severe & 3 & 2.3 \\
Total & 133 & 100.0 \\
\hline
\end{tabular}


Table 2: Level of Depression

\begin{tabular}{ccc}
\hline Level & Frequency & Percentage \\
\hline Normal & 0 & 0 \\
Mild & 0 & 0 \\
Moderate & 55 & 41.4 \\
Severe & 78 & 58.6 \\
Total & 133 & 100.0 \\
\hline
\end{tabular}

Table 3: Relationship between Academic Stress and Depression

\begin{tabular}{lccc}
\hline Variable & \multicolumn{3}{c}{ Depression } \\
\hline & $\mathbf{N}$ & $\mathbf{r}$ & Sig. \\
\hline Academic stress & 133 & .656 & .000 \\
\hline Notes. ${ }^{*} p<.05$. & & & \\
\hline
\end{tabular}

\section{Discussion}

Level of Stress

Table 1 shows the level of academic stress among medical students. The results of this study indicate that the majority of respondents in USIM have mild levels of academic stress. This result contradicts a study by Barikani (2009) who reported high levels of stress among students due to living away from home and coping with new programmes of study. These contrasting findings may be due to the different environments as the students in this study were at home because of the Movement Control Order. However, the findings of this study are supported by Lee and Graham (2001) who noted lower levels of stress among medical students living with their families compared to those living alone on campus. Other studies report that individuals having strong social support experience lower levels of stress and have a higher degree of tolerance to it (The et al., 2015).

\section{Level of Depression}

As Table 2 shows, the majority of respondents had severe levels of depression. This is in line with a study on medical students in Karachi (Shabbir \& Bashir, 2016). This is because apart from the usual stresses in daily life, medical students also have to deal with stress in medical school (Jadoon et al., 2010). However, Gin and Yuen (2019) reported low rates of depression among students because they are adults, experienced in facing exams, and have acquired skills for coping with the curriculum. The high level of depression found in this study was due not only to academic factors but also the economic status of the students and the environment. A study by Ibrahim, Kelly, Adams, and Glazebrook (2013) showed that students from poor family backgrounds and occupational parents are predisposed to depression. This is supported by Bayram and Bilgel (2008) who reported that students from rural environments tended to have higher levels of depression than those from urban areas. This may be due to 
economic factors where families in rural areas generally have lower economic status (Shamsuddin et al., 2013).

Relationship between academic stress and depression

Table 3 shows the positive relationship between academic stress and depression among medical students. This is consistent with the findings of Arul et al. (2015) who state that students with high academic stress are also at high risk of experiencing depression. In addition, Fares et al (2016) found that high levels of academic stress, in turn, had a negative impact on emotional burnout among medical students and contributes to anxiety and depression.

\section{Conclusion}

In producing high quality medical personnel, the element of academic stress and depression should be of concern to medical universities and colleges. Every aspect that might contribute to higher levels of academic stress and depression should be addressed and managed as early as possible. The institutions should encourage and provide a warm and affective learning environment for students in managing such issues. The training of medical students as future doctors entails more than just facilitating the development of expertise and skills and involve a holistic approach to ensure they can cope with and adhere to professional principles and conduct. In order to gain in-depth understanding of the issue of academic stress and depression among medical students, this study can be expanded by using qualitative research methods in the future. Through this method, detailed and more comprehensive information can be obtained and understood which in turn can assist in the formulation of strategies and programs for managing such mental health issues among medical students.

\section{Corresponding Author}

Abdul Rashid bin Abdul Aziz

Faculty of Leadership and Management Universiti Sains Islam Malaysia, 71800, Bandar Baru

Nilai, Negeri Sembilan, Malaysia

Email: rashid@usim.edu.my

\section{References}

Aziz, A. R. A., Shafie, A. A. H., Lee, U. H. M. S., \& Ashaari, R. N. S. R. (2020). Strategi pembangunan aspek kesejahteraan kendiri bagi mendepani tekanan akademik semasa wabak Covid-19. Malaysian Journal of Social Sciences and Humanities (MJSSH), 5(12), 16-30.

Arul, J., Thirunavukaras, M., \& Rajamanickam. (2015). Academic stress and depression among adolescents: a cross-sectional study. Journal Indian Pediatrics, 52, 217-219.

Shah, A. (2011). Development validity and reliability of student stress inventory. The Social Sciences, 10(7), 1631-1638.

Adlaf, E., Gliksman, L., Demers, A., \& Newton, B. (2001). The prevalence of elevated psychological distress among Canadian undergraduates: findings from the 1998 Canadian campus survey. Journal of American College Health, 50, 67-72.

Barikani, A. (2009). Stress in medical students. Journal Medical Educ, 11, 1-2. 
Bayram, N., \& Bilgel, N. (2008). The prevalence and socio-demographic correlations of depression, anxiety and stress among a group of university students. Social Psychiatry and Psychiatric Epidemiology, 43, 667-72.

Blachnio, A., Przepiorka, A., \& Pantic, I. (2015). Internet use, Facebook intrusion, and depression: Results of a cross-sectional study. European Psychiatry, 2-5.

Coentre, R., \& Góis, C. (2018). Suicidal ideation in medical students: recent insights. Advances in Medical Education and Practice, 9, 873-880.

Cole, N. N., Nonterah, C. W., Utsey, S. O., Hook, J. N., Hubbard, R. R., Opare-Henaku, A., \& Fischer, N. L. (2015). Predictor and moderator effects of ego resilience and mindfulness on the relationship between academic stress and psychological wellbeing in a sample of Ghanaian college students. Journal of Black Psychology, 41, 340-357.

Dahlin, M., Joneborg, N., \& Runeson, B. (2005). Stress and depression among medical students: a cross-sectional study. Medical education, 39, 594-604.

Debjit, B. K. P., Kumar, S., Srivastava, S., Paswan, S., \& Dutta, A. S. (2012). Depression Symptoms, Causes, Medications and Therapies, The Pharma Innovation, 1(3), 41-55.

Desmita. (2009). Psikologi perkembangan peserta didik: Panduan bagi orang tua dan guru dalam memahami psikologi anak usia SD, SMP dan SMA. Bandung: PT Remaja Rosdakarya.

Dinas, P., Koutedakis, Y., \& Flouris. (2011). Effects of exercise and physical activity on depression. Ir J Med Sci, 2, 319-325.

Abadi, E. I., M., Kouhi, F., Mazloum, S., \& Navidian, A. (2002). Prevalence of depression among students of Zabol Medical School. Journal of Shahrekord University of Medical Sciences, 6(2), 15-21.

Fares, J., Al Tabosh, H., Saadeddin, Z., El Mouhayyar, C., \& Aridi, H. (2016). Stress, burnout and coping strategies in preclinical medical students. North American Journal of Medical Sciences, 8, 75-81.

Gin, G. G., \& Yuen L. H. (2019). Anxiety, depression and quality of life of medical students in Malaysia. Med J Malaysia, 74, 57-61.

Ibrahim, A. K., Kelly, S. J., Adams, C. E., \& Glazebrook, C. (2013). A systematic review of studies of depression prevalence in university students. Journal of Psychiatric Research, 47, 391-400.

Jadoon, N. A., Yaqoob, R., \& Raza, A., Shehzad, M. A., \& Zeshan, S. C. (2010). Anxiety and depression among medical students: a cross-sectional study. Journal Pak Med Assoc. 60. 699-702.

Jafri, S. A. M., Zaidi, E., Aamir, I. S., Aziz, H. W., Din, I., \& Shah, M. A. H. (2017). Stress Level Comparison of Medical and Non-medical Students: A Cross Sectional Study done at Various Professional Colleges in Karachi, Pakistan. Acta Psychopathol. 3:2.

Jayanthi, P., Thirunavukarasu, M. \& Rajkumar, R. (2015). Academic stress and depression among adolescents: a cross-sectional study. Journal of Indian Pediatric, 52, 217-219.

Kadri, H. M., Al-Moamary, M. S., Magzoub, M. E., Roberts, C., Vleuten, C. P. M. (2011) Students' perceptions of the impact of assessment on approaches to learning: A comparison between two medical schools with similar curricula. Int J Med Educ, 2, 4452.

Kbede, M. A., Anbessie, B., \& Ayano, G. (2019). Prevalence and predictors of depression and anxiety among medical students in Addis Ababa, Ethiopia. International journal of mental health system, 13, 30. 
Khadijatu, M. (2018). The relationship between depression and academic performance among undergraduate students. International Journal of Education and Evaluation, 4.

Kumar, S., Kattimani, \& Sarkar, S. (2016). Prevalence of depression and its relation to stress level among medical students in Puducherry, India. Industrial Psychiatry Journal, 26, 8690.

Lee, J., \& Graham, A. (2001). Students' perception of medical school stress and their evaluation of a wellness elective. Journal Med Educ, 35, 9-652.

Le Fevre, M., Matheny, J., \& Kolt, G. S. (2003). Eustress, distress, and interpretation in occupational stress. Journal of Managerial Psychology, 18, 726-744.

Manjunath, R., \& Kulkarni, P. (2013). Mental Health Status and Depression among Medical Students in Mysore, Karnataka - An Untouched Public Health Issue. Natl J Community Med, 4(1), 50-3.

Mental Health Atlas. (2017). World Health Organization (WHO). Retrieved on $1^{\text {st }}$ May 2021 from https://www.who.int/mental_health/evidence/atlas/atlas_2017_web_note/en/

Bahri, M. S., Fuad, A. A. R., \& Jamil, Y. (2010). Prevalence and Sources of Stress among Universiti Sains Malaysia Medical Students. Malaysian Journal Medical Science, 17(1), 30-37.

Arif, J., \& Sa'odah, A. (2019). Persepsi Tekanan Akademik dan Kesejahteraan Diri di dalam Kalangan Pelajar Universiti di Serdang, Selangor. Journal of Social Sciences, 5(1), 24-36.

Moran, R. N., Crutcher, B., \& Covassin, T. (2018). Examining the relationship between social support satisfaction and perceived stress and depression in athletic training students. Athletic Training Education Journal, 13, 168-174.

National Health and Morbidity Survey (NHMS). (2017). Malaysia Ministry of Health. Retrieved on 20th April 2021 from http://iku.moh.gov.my/images/IKU/Document/REPORT/NHMS2017

Oku, A. O., Owoaje, E. T., Oku, O. O., \& Ikpeme, B. M. (2015). Prevalence of stress, stressors and coping strategies among medical students in a Nigerian medical school. African Journal of Medical and Health Sciences, 14, 29.

Preeti, S., \& Mustafa, N. (2013). Exploring depression \& anxiety among college going students. International Journal of Science and Research, 4, 438.

Rahul, G. K., \& Vikas, S. M. (2018). Academic stress and depression among college students. International Journal of Current Research, 10, 76429-76433.

Shabbir, M. H., \& Bashir, U. (2016). Depression among medical students. Journal Psychol Clinic Psychiatry , 6, 3-71.

Shamsuddin, K., Fadzil, F., Ismail, W. S. W., Shah, S. A., Omar, K., Muhammad, N. A., \& Mahadevan, R. (2013). Correlates of depression, anxiety and stress among Malaysian university students. Asian journal of psychiatry, 6(4), 318-323., http://dx.doi.org/10.1016/j.ajp.2013.01.014

Simmons, B. L., \& Nelson, D. L. (2001). Eustress at work: the relationship between hope and health in hospital nurses. Journal Health Care Management Review, 26, 7-18.

Sindhu, P. (2016). Impact of depression on academic achievement among engineering students. International Journal of Indian Psychology, 4, 82.

Skevington, S. M., \& McCrate, F. M. (2012). Expecting a good quality of life in health: assessing people with diverse diseases and conditions using the WHOQOL-BREF. Journal of Health Expect, 1, 49-62.

Skipworth, K. (2011). Relationship between Perceived Stress and Depression in College Students, Thesis Master of Science, Arizona State University. 
Nurhayati, S. S., Fonny, D. H., \& NoorAishah, R. (2020). Pengaruh Stres Akademik, Daya Tindak dan Adaptasi Sosial Budaya Terhadap Kesejahteraan Psikologi Pelajar Universiti. Jurnal Kepimpinan Pendidikan, 7(2), 36-57.

Sydenham, M., Beardwood, J., \& Rimes, K. A. (2017). Beliefs about emotions, depression, anxiety and fatigue: A mediational analysis. Behavioural and Cognitive Psychotherapy, 45(1), 73-78.

Teh, C. K., \& Ngo, C. W., Zulkifli, R., \& Vellasamy, R. (2015). Depression, anxiety and stress among undergraduate students: a cross sectional study. Open Journal of Epidemiology, 5, 260-268.

Toro-Tobar, R., Grajales-Giraldo, F., Sarmiento-López, J. (2016). Riesgo suicida según la tríada cognitiva negativa, ideación, desesperanza y depresión. Aquichan, 16(4), 473-486.

Truschel, J. (2019). Depression Definition and DSM-5 Diagnostic Criteria. Retrieved on 1st December 2019 from https://www.psycom.net/depression-definition 